\title{
Small-scale maize seed production in West and Central Africa: Profitability, constraints and options
}

\author{
Awotide Diran Olawale ${ }^{1, *}$, Mafouasson Hortense Noelle Tontsa ${ }^{2}$ \\ ${ }^{1}$ Department of Agricultural Economics and Farm Management, Olabisi Onabanjo University, Yewa Campus, Ayetoro, Ogun State, Nigeria \\ ${ }^{2}$ Institut De Recherche Agricole Pour Le Developpement (IRAD), Yaoundé, Cameroon
}

Email address:

w_awotide@yahoo.com (Awotide D. O.)

\section{To cite this article:}

Awotide Diran Olawale, Mafouasson Hortense Noelle Tontsa. Small-Scale Maize Seed Production in West and Central Africa: Profitability, Constraints and Options. American Journal of Agriculture and Forestry. Vol. 3, No. 1, 2015, pp. 1-10. doi: 10.11648/j.ajaf.20150301.11

\begin{abstract}
Seed plays a critical role in increasing agricultural productivity. Seed has been described as an essential, strategic, and relatively inexpensive input that often determines the upper limit of crop yields and the productivity of all other agricultural inputs. Given the critical role that seed plays in agricultural production, a key question is how to facilitate the development of a seed system that is capable of generating, producing and distributing new seed varieties that meet the needs of all farmers, in a cost-effective way given the critical role that improved varieties play in increasing agricultural production. The study was conducted in Nigeria and Cameroon in West and Central Africa respectively. A multi-stage sampling technique was used in this study to select 167 maize seed producers. Descriptive and quantitative techniques were employed in the analysis of the study data. Descriptive analytical tools such as frequency tables were used to describe the socio economic characteristics of respondents and options in maize seed production. Normalised profit function analysis was used to determine the profitability of seed production and importance indices were used to rank seed production constraints. Finally regression analysis was used to determine the factors affecting the profitability of maize seed production. The survey conducted in the two countries revealed that there is no formal maize seed production system in Cameroon. Maize seed in Cameroon came from either the government agencies or from the farmers. However, in Nigeria, there is formal maize seed production system. Evidence from the study has shown that maize seed industry in WCA (Nigeria and Cameroon in particular) has not developed remarkably. According to study, a seed system that would integrate large scale and small scale seed companies with the individual seed producers by way of integrating seed producers as out growers or contract growers to the seed companies seems to be the best option. Finally, government agencies could assist the informal sector by providing foundation seed, extension advice on seed production, processing, treatment and storage and legal framework that permits seed marketing. This would facilitate the growth of small-scale entrepreneurs in the informal sector. This is very relevant in Cameroon where there were no small-scale formal seed producers. The evidence provided in this study could lead to the sustainability of maize seed production in WCA where seed companies exist but struggling to survive and could facilitate the establishment of private seed enterprises in Cameroon where none existed. Based on the findings, numerous policy recommendations are proposed.
\end{abstract}

Keywords: Maize Seed Producers, Profitability, Constraints Analysis, Options for Integration, West and Central Africa

\section{Introduction}

There is general agreement among national governments and foreign aid donors that the food security situation in most developing countries is worsening. In the African region, almost half the population is being considered to be food insecure. To achieve food security, a country must be able to grow sufficient food. Since most developing countries rely on their agricultural production for their food security, it follows that food insecurity is mainly due to deficient agricultural production and low productivity. A main reason for this situation is that seed and planting material of adapted varieties required by farmers are not always available when needed, a situation often referred to as seed insecurity. There have been consistent efforts by the various national governments to put in place policies and programmes that ensure adequate seed supply systems (Omaliko, 1998).

Seed can play a critical role in increasing agricultural productivity. Seed has been described as an essential, strategic, and relatively inexpensive input that often 
determines the upper limit of crop yields and the productivity of all other agricultural inputs (Maredia and Howard, 1994; Langyintuo, 2005). Given the critical role that seed play in agricultural production, a key question is how to facilitate the development of a seed system that is capable of generating, producing and distributing new seed varieties that meet the needs of all farmers, in a cost-effective way given the critical role that improved varieties play in increasing agricultural production (Maredia and Howard, 1998).

However, the key to the availability of the seed will be the profitability and riskiness of seed production relative to alternative uses of farmers' limited land and labor resources. Accessible market outlets and high output-input price ratios are the key farmer incentives for sustainable adoption of modern inputs and increased production of seed and grain for the market. If farmers are to produce and supply improved maize seed and grain on a sustainable basis, the market should offer higher grain prices, and seed prices that are high enough to more than offset the costs of seed production, which are usually higher than the cost of grain production.

In many developing countries, small farmers are not considered efficient contract seed growers, and some important crops grown by them are of limited commercial interest to seed companies (Venkatesan, 1994). This limits the diffusion and use of improved varieties and quality seed by small farmers, thus contributing to low productivity. Seed industry in West and Central Africa (WCA) is plagued with myriads of problems. These include collapse of many large scale farms; non-profitability and capacity under-utilization by existing private seed companies; unawareness of the problems of pricing and production costs; seed quality problem; fake seed and flagrant use of grains as seeds in vital projects; and problems of rural sales outlets. Since countrylevel case studies could provide useful information concerning the economics of smallholder seed organizations, this study attempts to examine profitability of and constraints to seed production with respect to maize. These are considered the two key problems facing seed industry in WCA. Thus, the objectives of the study are to:

1. conduct econometric analysis of maize seed profitability

2. identify the constraints of maize seed production in the study area,

3. identify the criteria used by maize seed farmers to select seed for production

4. develop strategies and options for the integration of informal and formal maize seed producers to promote farmer incentives for maize seed production.

\section{Maize Production in WCA}

Maize production ranks second among the major cereal grains and it is a major cereal crop in West and Central Africa (WCA), currently accounting for a little over $20 \%$ of domestic food production in Africa (Manyong et al. 2000). Its importance has increased as it has replaced other food staples, particularly sorghum and millet (Smith et al. 1994), and it has also become a major source of cash for smallholder farmers (Smith et al. 1997). However, farm holdings are mainly small scale and studies have shown that drought, low soil fertility, insect pests, striga and maize streak virus are the major constraints to maize production in Africa. Trends in maize production indicate a steady growth and could be attributed to the expansion of cultivated area. It was observed that about 26 million tons of maize is produced annually in Africa on 20 million hectares of land (Byerlee and Eicher, 1997). During the period 1980 to 1997, maize production in Africa grew at an average annual rate of about two percent per annum (Abamu, 2001).

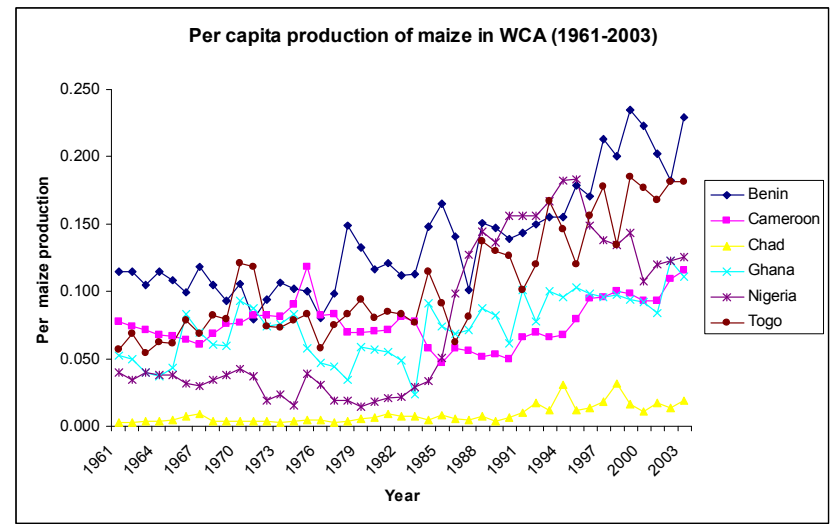

Figure 1. Per capita production of maize in WCA (1961-2003)

Maize yields in WCA have been highly variable as a result of climatic factors as well as price variability (Abalu, 2001) and by many biotic stresses (Fakorede et al. 2003). Some of the factors responsible for the low yield in farmers' field are weeds, pests, diseases, soil fertility and crop management practices (Fakorede et al. 2001). Figure 1 and Table 1 show the trend on the per capita maize production in WCA for the period 1961-2003. The figure and the table show the fluctuation in maize production over time. This may be due to price variability (Abalu, 2001) and many abiotic stresses (Fakorede et al. 2003).

Table 1. Average per capita production of maize in WCA

\begin{tabular}{lllllll}
\hline Period & Benin & Cameroon & Chad & Ghana & Nigeria \\
\hline $1961-1965$ & 0.111 & 0.072 & 0.004 & 0.044 & 0.038 \\
$1966-1970$ & 0.104 & 0.069 & 0.005 & 0.073 & 0.035 \\
$1971-1975$ & 0.096 & 0.091 & 0.004 & 0.076 & 0.027 \\
$1976-1980$ & 0.115 & 0.075 & 0.004 & 0.048 & 0.086 \\
$1981-1985$ & 0.132 & 0.067 & 0.007 & 0.058 & 0.085 \\
$1986-1990$ & 0.136 & 0.054 & 0.005 & 0.074 & 0.078 & 0.132 \\
$1991-1995$ & 0.156 & 0.070 & 0.016 & 0.096 & 0.169 \\
\hline
\end{tabular}




\begin{tabular}{lllllll}
\hline Period & Benin & Cameroon & Chad & Ghana & Nigeria & Togo \\
\hline $1996-2000$ & 0.208 & 0.097 & 0.018 & 0.095 & 0.134 & 0.166 \\
$2001-2003$ & 0.205 & 0.106 & 0.017 & 0.106 & 0.123 & 0.177 \\
\hline
\end{tabular}

Source: Computed from faostat data

\section{Maize Seed Industry}

Despite the importance of improved seed for bettering the welfare of small-scale farmers, access to this invaluable technology can be constrained by many factors, including an underdeveloped seed industry (Gemeda, et al. 2001). According to Pray and Ramaswami (1991) a seed industry essentially consists of all the enterprises that produce or distribute seed and has four components: 1) plant breeding and research, 2) seed production and multiplication, 3) processing and storage, and 4) marketing and distribution. However, the industry's performance depends on the efficiency of each component, and each component possesses different economic and technical characteristics that determine the roles that public and private organizations play within the industry (Gemeda, et al. (2001). The performance of the seed industry necessitated the development of an ideal seed system. An ideal system ought to ensure adequate supply of quality seeds for modern varieties at affordable prices in the right time. Hossain, et al. (2003) noted that an ideal seed system needs supportive institutional and policy conditions for active participation of all key entities and for strengthening the public-private interface to play their basic roles in an efficient way.

Seed system development can be viewed as a dynamic process of matching the supply to the changing demand for seeds. The seed system passes through several phases as it evolves from a traditional to advance system. Maize industry in Africa is undergoing rapid changes (Nambiro et al. 2002) and its development seems to follow the same path (Morris et al. 1998). In the early stages of the seed industry, only the public sector can make the necessary heavy investment for research, development, and marketing of seed. However, when the sector expands and develops, seed production and distribution becomes increasingly interesting for the private sector. In the final stages, the private sector can take over increasing parts of the research too. The nature and pace of these changes have varied among countries, reflecting differences in stages of development and the structure of production from one country to the next, as well as differences in the economic, political and institutional climates (Nambiro et al. 2002).

Seeds of the varieties and land races of our food crops provide the biological basis for food security. There has been a number of complementary efforts by public institutions and private seed companies to provide seed to farmers. Despite these efforts and arrangements, the availability and adoption of improved seed varieties to rural farmers is still very low in Nigeria (Fakorede, 1995) and South Africa (Langyintuo, 2005). The low adoption rate was attributed to relatively high cost of hybrid (compared to open pollinated varieties (OPV)) and its suitability for optimal maize growing conditions - good water regimes and high soil fertility (Langyintuo, 2005). As a result, farmers in many African communities are yet to have access to improved seeds. Most seeds planted by farmers come from local sources including farmers' own crop, neighbors, and relatives, or from local markets (Cromwell et al. 1992; Jaffee and Srivastava 1994; Louwaars and Marrewijk 1999). This has resulted in yield potential losses especially under the poor seed management system adopted by the farmers. Most small scale, resource poor farmers prefer the farmer seed systems to the market source of seed supply as it ensures local seed security, both a function of availability and access although quality may be poor. Seed availability generally refers to the amount of seed harvested, timeliness of the harvest and the sustainability of the supply. Seed access on the other hand relates to the quality (desired variety with the right genetic and sanitary criteria for producing a crop), equity in distribution (to all farmers) and the ability to have from external sources (through financial means) (Langyintuo, 1995).

In Africa, seed parastatals were not effective in meeting the needs of smallholders, private seed firms have not yet filled the gap and smallholder access to improved varieties has worsened in a number of countries following economic reforms (Maredia et al. 1999). This observation and situation suggests the existence of problems in African's seed system. These are in spite of the agricultural seed policy, the legal framework, and the institutional arrangements put in place to ensure success of the seed system. Not many countries have adequately addressed the question of providing farmers with access to good quality planting material, particularly of the modern varieties. In most countries, government policies relating to the regulation of seed production and price-setting inhibit the emergence of private initiatives in seed production and distribution (Venkatesan, 1994).

A well-functioning seed system is defined as one that uses the appropriate combination of formal, informal, market and non-market channels to efficiently meet farmers' demand for quality seeds. The seed system is composed of organizations, individuals and institutions involved in different seed system functions, i.e., the development, multiplication, processing, storage, distribution and marketing of seeds. The seed system includes both informal and formal sectors. The formal sector, is composed of public and private organizations with specialized roles in supplying new varieties. However, the formal seed sector alone is not sufficient to meet farmers' seed needs, and hence cannot produce a sustainable increase in production and productivity to realize Africa objectives of food self-sufficiency and food security. For example, the estimate of the percentage of farmers who purchase seed produced by formal institutions such as parastatal seed organizations and private seed companies in Sub-Saharan Africa ranges from $5 \%$ to $10 \%$ (Venkatesan, 1994). This 
suggests that a large percentage of farmers use their own saved seed or seed obtained from other farmers in their communities.

The informal sector is composed of individual farm households, each carrying out most seed system functions on its own, with little or no specialization. Literature is replete on the development of viable farmer seed systems (Brush et al. 1982; Almekinders et al. 1994; Jaffee and Srivastava, 1994; Ghijsen, 1996; Musa and van der Mheen-Sluijer, 1997; Musa and Rusike, 1997; Rohrbach, 1997; Tripp, 1997; Monyo, 1998).

\section{Research Methodology}

\subsection{Study Areas, Sampling Procedure and Sample Size}

The study was conducted in Nigeria and Cameroon in West and Central Africa respectively. In Nigeria, maize seed production is concentrated in the Northern part of the country. As a result, Kaduna state from the North was chosen. In like manner, seed production is concentrated in the North and central division of Cameroon. However, because of the population of maize seed producers, two divisions were chosen. A multi-stage sampling technique was used in this study. In the first stage, two divisions in Cameroon and one state in Nigeria were selected. In the second stage of the sampling technique, five communities/villages were selected. From each village, 50 seed producers were initially intended to be chosen using snowball sampling technique. However, in practice, 82 maize seed producers in Cameroon and 85 maize seed producers were used for the study and thus, constituting the third stage of the sampling. In all, 167 questionnaires were distributed for data collection. Questionnaire administration was undertaken in both countries by local enumerators selected from the agricultural development sector. The enumerators were trained in the use of the questionnaires which was piloted in the local language in non-target villages prior to the survey.

\subsection{Method of Data Analysis}

Descriptive and quantitative techniques were employed in the analysis of the study data. Descriptive analytical tools such as frequency tables were used to describe the socioeconomic characteristics of respondents and options in maize seed production. Normalised profit function analysis was used to determine the profitability of seed production and importance indices were used to rank seed production constraints. Finally regression analysis was used to determine the factors affecting the profitability of maize seed production.

\subsection{Model Formulation/Analytical Technique: Normalised Profit Function}

Normalised restricted profit function was used to determine the profitability of maize seed farmers. The analytical framework is presented below.

Using the output price as the numeraire, the normalised profit function $(\pi *(q, Z))$ can be written in a generalized form as:

$$
\pi *(q, Z)=F\left[X_{1} *(q, Z) \ldots \ldots, X_{n} *(q, Z)\right]-\sum_{j=1}^{m} q_{j} X_{j}^{*}(q, Z)
$$

Where $q_{j}$ represents the normalised factor prices, $\mathrm{F}$ is a well-behaved production function, $\mathrm{X}$ is the vector of variable inputs and $Z$ is the vector of fixed inputs used in the production process. Starting with any well-specified normalised restricted profit function, direct application of Hottelings - Shepherd's Lemmas to the function yields the corresponding factor demand and output supply equations.

$$
\partial \pi *(q, Z) / \partial q_{j}=-X_{j} * \mathrm{j}=1, \ldots \ldots, \mathrm{m}
$$

Multiplying both sides by $q_{j} / \pi *$ gives a series of $\mathrm{m}$ factor share equations.

$$
\left[\partial \pi^{*}(q, Z) / \partial q_{j}\right]=-X_{j}^{*} q_{j} / \pi^{*}=\alpha_{j}^{*} \mathrm{j}=1, \ldots \ldots, \mathrm{m}
$$

Equations (1) and (3) form the theoretical basis for the specifications of the model.

For this study, the specification of the systems of equations of the normalized profit function equation is given as

$$
\operatorname{In} \pi_{i}^{*}=\operatorname{In} \mathrm{A}^{*}+\alpha^{*} \mathrm{~L}+\delta^{*} D+\sum_{i=1}^{2} \theta_{i} * \operatorname{In} w_{i}+\sum_{i=1}^{2} \beta_{i}^{*} \operatorname{In} Z_{i}+\psi_{i}
$$

Where $\pi^{*}$ is the normalized profit defined as revenue less variable costs normalized by the price of maize seed $(\mathrm{P})$.

$\mathrm{A}^{*}=$ the intercept

$\mathrm{X}_{1}=$ the number of hours of labor used including family and hired labor.

$\mathrm{X}_{2}=$ the quantity of seeds used in maize seed production (kg)

$\mathrm{W}_{1}=$ the wage rate normalised by the price of maize seed.

$\mathrm{W}_{2}=$ the price of maize seed.

$\mathrm{Z}_{1}=$ the capital inputs and is the sum of the costs of various implements used in maize seed production.

$\mathrm{Z}_{2}=$ the land input in hectares.

$\mathrm{D}=$ the dummy variable taking the value of unity for outgrowers and zero for non out-growers.

$\mathrm{L}=$ Technical linkage is dummy variable taking the value of unity for growers that have links with institutions and zero otherwise.

$$
\begin{aligned}
& \alpha, \theta_{i}, \text { and } \beta_{i} \text { are parameters to be estimated } \\
& \psi_{i} \text { is error term }
\end{aligned}
$$

\subsection{Regression Analysis}

Ordinary Least Squares (OLS) estimation was used to explain the variation in profit between farmers using profit $\left(\pi^{*}\right)$ as the dependent variable and a range of socioeconomic and demographic factors of growers as the explanatory variables as follows:

$\mathrm{X}_{1}=$ Age of farmer in years 
$\mathrm{X}_{2}=$ Education of farmer expressed in number of school years

$\mathrm{X}_{3}=$ Ecological zone $(1=$ single rainfall regime and $0=$ double rainfall regime)

$\mathrm{X}_{4}=$ Household headship $(1=$ male and $0=$ female $)$

$\mathrm{X}_{5}=$ Membership of association $(1=$ yes and $0=$ no $)$

$\mathrm{X}_{6}=$ Earnings from off farm activities in monetary value

$\mathrm{X}_{7}=$ Access to extension services $(1=$ yes and $0=$ no $)$

$$
\pi * \delta_{0}+\delta_{1} \mathrm{X}_{1}+\delta_{2} \mathrm{X}_{2}+\delta_{3} \mathrm{X}_{3}+\delta_{4} \mathrm{X}_{4}+\delta_{5} \mathrm{X}_{5}+\delta_{6} \mathrm{X}_{6}+\ldots \ldots+\delta_{10} \mathrm{X}_{10}+\mathrm{e}
$$

\subsection{Constraints Analysis - Importance Indices}

Importance indices were constructed to identify the relative importance of constraints in maize seed production. Maize seed producers were asked to rank the identified constraints to maize seed production on an ordinal scale (1 being assigned to the most important). The use of important index in constraint analysis is replete in the literature (Jose and Valluru, 1997; Alimi, 2001; Alimi et al. 2004).

\section{Results and Discussion}

\subsection{Formal Maize Seed Production System in Nigeria and Cameroon}

The survey conducted in the two countries revealed that there was no formal maize seed production system in Cameroon. Maize seed in Cameroon came from either the government agencies or from the farmers. However, in Nigeria, there was formal maize seed production system. The National Seed Programme in Nigeria has recognized three tiers of participants in the industry: 1) Large scale seed companies, small/medium seed enterprises, and 3) community seed system (informal sector). There were few seed producing companies in Nigeria. The industry is gradually transforming from a marketing enterprise to a producing/processing and marketing one. A major constraint in the development of seed industry in the country was lack of adequate manpower. During the survey period, not more than ten percent of the required trained personnel were available in the country.

\subsection{Large Scale Seed Companies}

At the moment, the companies that fall in this category include Premier Seeds Nig. Ltd., (Zaria), Alheri Seeds Nig
$\mathrm{X}_{8}=$ Number of field days attended by the respondents

$\mathrm{X}_{9}=$ Seed production experience in years

$\mathrm{X}_{10}=$ Household size

The following equation describing the relationships between gross margin and the explanatory variables was therefore postulated, where $\delta \mathrm{i}$ are regression coefficients and e an error term:

Ltd (Zaria), Savannah Seeds and Livestock Ltd., (Jos), Nagari Seeds Ltd., (Zaria), Maslaha seeds (Gusau), and Seed Project, (Kaduna).

\subsection{Small/medium seed Enterprises}

In this category, Agricultural Development Programmes (ADP) is expected to identify suitable out-growers with adequate potentials to develop into small-scale seed enterprises. Such growers are assisted with fertilizer, agrochemicals, credit and other production inputs at full cost recovery. Furthermore interested growers who would like to float full scale seed enterprises are assisted with training and provision of seed processing equipments on hire purchase, custom processing or outright purchase.

\subsection{Informal Maize Seed Production System}

The community seed programme is aimed at making good quality seed available to farmers at very cheap prices and within the shortest possible distance. Agricultural Development Programmes (ADPs) were expected under this porgramme to select 100 Village Extension Agents (VEAs) who would identify a contact farmer each. Each contact farmer would be assisted by the ADP and National Agricultural Seed Council (NASC) to establish 1 ha per contact farmer of the most preferred crop and variety in his community. Seeds harvested from these plots were given such publicity that would enable easy distribution within the community of origin. Farmers' seed production essentially refers to growing a crop of which part is saved as seed for own use. Saving the best grains from consumption, their storage and planting developed over centuries into structured local seed systems.

\subsection{Socioeconomic Characteristics of Maize Seed Farmers}

Table 2. Summary description of maize seed farming household characteristics

\begin{tabular}{|c|c|c|c|c|}
\hline Characteristics & Dominant indicator & Mean value (Pool) & Mean value (Nigeria) & Mean value (Cameroon) \\
\hline Age & $43 \%$ were aged between $40-50$ & 42.4 & 43.7 & 41.0 \\
\hline Formal education & $62 \%$ had more than 6 years & 8.7 & 7.3 & 10.1 \\
\hline Household size & $52 \%$ had between $1-6$ people & 8.5 & 10.9 & 6.0 \\
\hline Experience in maize & $40 \%$ had between $11-20$ years & 15.9 & 16.2 & 15.5 \\
\hline Experience in seed & $78 \%$ had between $1-4$ years & 3.5 & 4.1 & 2.9 \\
\hline Farm size & $53 \%$ had between $1-2$ ha & 1.8 & 2.5 & 1.1 \\
\hline Maize seed output (kg) & $42 \%$ had more than $3000 \mathrm{~kg}$ & 4034 & 6985 & 976 \\
\hline Access to credit & $83 \%$ did not have access to credit & - & - & - \\
\hline
\end{tabular}

Source: Field survey, 2008 
Summary statistics of some important socio-economic variables are presented in Table 2. The results showed that the mean age of farmers in the study area was 42 years. This suggests that the farmers are relatively young (WHO, 1991). This gives hope for promising future of maize seed production in the Nigeria and Cameroon. Table 2 also shows that the respondents on the average had nine years of formal education. The literacy level was high among the sampled farmers. This would have positive effect on their choice of inputs and the utilization of existing inputs as well as their willingness to adopt improved technologies. Mean profit per production season made by maize seed farmers was $\$ 3716$. From the descriptive statistics of the socio-economic profile of the farmers, it could be observed that 78 percent of the maize seed farmers had 1-4 years of experience. Furthermore, 50 percent of farmers made up to $\$ 2400$ per year on maize seed production in spite of the fact that more than $80 \%$ did not have access to credit.
The results of the estimated normalised profit function are presented in Table 3. The coefficients of labor input, seed input, land area and capital were significant at between one percent and five percent levels of significance in the pooled model. As expected, the coefficient of labor price (wage rate) and seed price are negatively signed indicating that the estimated profit function is convex in input prices. As costs they lower the profit made by the rice farmers. The coefficient of capital input was positive. However, in Nigeria, seed input, capital input and farm size were significant at $1 \%$, $5 \%$ and $1 \%$ respectively while in Cameroon, all the variables considered were significant with the exception of seed price. One striking point to note is that in all the models, seed price was not significant. Finally, in Cameroon, there were no outgrowers and the growers had no link with any institution. In Nigeria, where they existed, the two variables were not significant in the normalized profit function model.

\subsection{Maize Seed Production Profitability}

Table 3. Normalized profit function form maize seed farmers in Nigeria and Cameroon

\begin{tabular}{|c|c|c|c|c|c|c|}
\hline \multirow[t]{2}{*}{ Variable } & \multicolumn{2}{|c|}{ Pooled data } & \multicolumn{2}{|l|}{ Nigeria } & \multicolumn{2}{|c|}{ Cameroon } \\
\hline & Coeff. & t-value & Coeff. & t-value & Coeff. & t-value \\
\hline Constant & 4.887 & $10.20 * * *$ & 7.972 & $27.61 * * *$ & 4.923 & $6.57 * * *$ \\
\hline Labor input & -0.929 & $-6.99 * * *$ & 0.295 & 0.98 & -0.846 & $-6.68 * * *$ \\
\hline Seed input & -7.316 & $-5.66 * * *$ & -8.549 & $-4.77 * * *$ & -4.510 & $-4.04 * * *$ \\
\hline Wage rate & -0.091 & 0.55 & -0.137 & -1.24 & -0.440 & $2.57 * *$ \\
\hline Seed price & -0.270 & -0.15 & -0.308 & -1.06 & -0.227 & 1.28 \\
\hline Capital & 0.309 & $6.80 * * *$ & 0.064 & $2.56 * *$ & 0.224 & $2.57 * *$ \\
\hline Out growers & 0.096 & 0.52 & -0.104 & -1.39 & - & - \\
\hline Linkage & -0.133 & -0.68 & 0.094 & 1.12 & - & - \\
\hline
\end{tabular}

Source: Field survey, $2008 * * *$ significant at $1 \%, * *$ significant at $5 \%$

\subsection{Factors Influencing Profitability of Maize Seed Producers}

Table 4. Factors affecting profit made by maize seed farmers in Nigeria and Cameroon

\begin{tabular}{|c|c|c|c|c|c|c|}
\hline \multirow{2}{*}{ Variable } & \multicolumn{2}{|c|}{ Pooled data } & \multicolumn{2}{|l|}{ Nigeria } & \multicolumn{2}{|c|}{ Cameroon } \\
\hline & Coeff. & t-value & Coeff. & t-value & Coeff. & t-value \\
\hline Constant $^{+}$ & 4117.35 & $2.65 * * *$ & 5026.32 & $1.79 *$ & 1439.14 & $2.81 * * *$ \\
\hline Ecological zone & -0.537 & $-5.80 * * *$ & - & - & - & - \\
\hline Age & -0.129 & -1.50 & -0.21 & -0.15 & -0.161 & -1.19 \\
\hline Household headship & 0.094 & 1.40 & - & - & 0.045 & 0.406 \\
\hline Formal education & -0.069 & -0.98 & -0.031 & -0.26 & 1.474 & 0.145 \\
\hline Household size & 0.182 & $2.01 *$ & 0.041 & 0.31 & 1.199 & 0.234 \\
\hline Earnings from off farm & -0.175 & $-2.37 *$ & -0.261 & $-2.59 * *$ & -0.131 & -1.03 \\
\hline Access to extension & 0.005 & 0.61 & 0.079 & 0.71 & -0.282 & $-2.29 * *$ \\
\hline Numbers of field days & 0.174 & $2.40 *$ & 0.536 & $4.98 * * *$ & 0.292 & $2.49 * *$ \\
\hline Seed production experience & 0.070 & 0.967 & 0.075 & 0.717 & -0.125 & -1.06 \\
\hline
\end{tabular}

Source: Field survey, $2008 * * *$ significant at 1\%, ** significant at 5\%, significant at 10\%, + unstandardized

The Ordinary Least Square estimates (OLS) of the parameters of the determinants of household farm income from maize seed production in Nigeria and Cameroon is presented in Table 4. Regression results from the pooled model showed that ecological zone specified as a dummy variable, where zero denotes bimodal and one monomodal was negative and was significant at 1 percent level suggesting profit of maize seed farmers is negatively related to bimodal. This explains why maize production is pronounced in the north than in the south. The negative coefficient of age implies that older farmers made more profit than the younger farmers. The coefficient for age variable was not a significant determinant of farmers' income. Headship was specified as a dummy variable, where one 
denotes male-headed household and zero otherwise. The coefficient of headship was positive and was not significant even at 10 percent level. The variable of education showed negative relation with farmers' income and not a significant determinant. The coefficient of household size was positive and was a significant determinant of farmers' income suggesting that maize farmers with large household size tend to make more profit in maize seed production. Membership of farmers association was significantly and positively related to farmers' profit in the study area.

Income generated from off-farm was statistically significant at $10 \%$ but negatively related to farmers' profit. Reason for the negative relation is not clear. It is expected that money generated from off-farm activities should boost the farmers' potentials to buy necessary inputs for maize seed production. However, if much of the farmers' time is devoted to off-farm activities this may jeopardize his seed production effort and thus has negative relation with profit made. Extension visits was not statistically significant but positively related to profit made from maize seed production. The reason for the positive correlation between extension visits and profitability is very clear. Frequency of visit by extension agents may increase farmers' knowledge of improved technologies and therefore increases profit made from maize seed production. On the contrary, field days attendance was statistically significant and positively related to maize seed profit. Finally, seed production experience was positively related to farm income but was not significant in determining farmers' income.

\subsection{Constraints to Maize Seed Production in Nigeria and Cameroon}

The perceived constraints to maize production in the two countries are presented in Table 5. The constraints were ranked from 1 (most important) to 6 (least important). Score of zero denotes no constraint. Table 5 reveals that about 68 percent of the respondents considered lack of access to credit facilities to be a constraint of least importance while 2.4 percent considered lack credit as the most important constraint. For seed, 28 percent of the sampled seed growers considered unavailability of foundation seed as the most important constraint while 13 percent considered it as the constraint of least importance. The variation in the percentages across scores for the other constraints is clearly shown in the table.

Table 5. Perceived constraints to maize seed production (percentage)

\begin{tabular}{lllllll}
\hline Scores & Credit & Labor & Market & Fertilizer & Seed & Land \\
\hline 0 & 2.4 & 8.5 & 9.8 & 2.4 & 7.3 & 9.8 \\
1 & 2.4 & 13.4 & 3.7 & 1.2 & 28.0 & 17.1 \\
2 & 0.0 & 26.8 & 8.5 & 6.1 & 23.2 & 25.6 \\
3 & 6.1 & 22.0 & 17.1 & 7.3 & 14.6 & 22.0 \\
4 & 7.3 & 9.8 & 13.4 & 19.5 & 3.7 & 11.0 \\
5 & 13.4 & 11.0 & 15.9 & 26.8 & 9.8 & 7.3 \\
6 & 68.3 & 8.5 & 31.7 & 36.6 & 13.4 & 7.3 \\
Total & 100.0 & 100.0 & 100.0 & 100.0 & 100.0 & 100.0 \\
\hline
\end{tabular}

Source: Field survey, 2008
Table 6 shows the constraints to maize seed production based on the sample of seed producers in Nigeria and Cameroon. According to the importance index, unavailability of foundation seed ranked first followed by unavailability of land. In this study, unavailability of land refers to inability of willing seed producers to access farm land for maize seed production. On the other hand, lack of access to credit facilities ranked last in order of importance. In the final analysis, the three most important constraints to maize seed production based on a sample of maize seed farmers in WCA were unavailability of foundation seed, unavailability of land, and unavailability of labor.

Table 6. Importance index of the constraints to maize seed production

\begin{tabular}{llll}
\hline Constraints & $\begin{array}{l}\text { Total value } \\
\text { of score }\end{array}$ & Index & Rank \\
\hline Lack of access to credit facilities & 432 & 5.3 & $6^{\text {th }}$ \\
Unavailability of labor & 228 & 2.8 & $3^{\text {rd }}$ \\
Market uncertainty for seed produced & 324 & 4.0 & $4^{\text {th }}$ \\
Unavailability of fertilizer & 383 & 4.7 & $5^{\text {th }}$ \\
Unavailability of foundation seed & 186 & 2.3 & $1^{\text {st }}$ \\
Unavailability of land & 212 & 2.6 & $2^{\text {nd }}$ \\
\hline
\end{tabular}

Source: Field survey, 2008

\subsection{Farmers' Criteria in Choosing Varieties}

Farmers use many but similar criteria in selecting the maize varieties they grow. Table 7 shows the main criteria farmers apply in choosing maize varieties they grow and the importance of each criterion. Importance of the choice of maize varieties was given a quantitative score using a scale of zero to five, with "very important" given the score $=5$, "low importance" a score $=1$ and 0 when the criterion was not mentioned. The scores were averaged for the countries, which allowed ranking the criteria in order of importance (Table 7).

Table 7. Farmers' choice of maize variety by country

\begin{tabular}{llll}
\hline Characteristics & Nigeria & Cameroon & Mean score \\
\hline Maturity period & 2.0 & 4.2 & 3.1 \\
Taste & 1.2 & 3.2 & 2.2 \\
Fertilizer requirement & 2.0 & 2.7 & 2.4 \\
Resistance to diseases & 1.7 & 4.2 & 3.0 \\
Grain quality & 2.2 & 4.3 & 3.3 \\
Cooking quality & 2.1 & 3.2 & 2.7 \\
Market value & 2.8 & 3.9 & 3.4 \\
Adaptability to poor soils & 2.5 & 2.4 & 2.5 \\
\hline
\end{tabular}

Source: Field survey, 2008

The most important criteria across the countries were, in that order: market value, grain quality, maturity period and resistance to disease. However, the scores of the criteria varied across the countries. Cooking quality, adaptability to poor soils, fertilizer requirement, and taste were the second group of criteria. These criteria received between 2.2 and 3.4 on the score of importance. Resistance to insects and other pests as a criterion for selection of maize varieties is very useful in practice if the attribute is combined with the most important criteria farmers apply in variety selection, thus 
adding value to the varieties (Odendo, et al. 2002).

\subsection{Options and Prospects of Integration}

Nigeria seemingly possesses great potentials for seed business, due to its land area, population and the status of the country in the West African Sub-regional trade. A flexible maize seed system is therefore crucial to effectively respond to these challenges. For a sustainable maize seed production system, the formal seed production sector in most countries should encourage the informal sector, which can meet the seed needs of a wide spectrum of farmers. The formal sector can continue producing hybrids and other high value seed along with the informal sector. Since, in most countries, informal farmer-to-farmer spread of seeds is the single most frequently used source of seed by farmers, it is necessary for governments to recognize the informal sector as an important low-cost source of quality seed, and to use it as a vehicle for providing resource-poor farmers with improved seed of modern varieties at affordable prices.

For a sustainable maize production, there is need to provide farmers with access to good seed within close distance, in time and at affordable prices. One workable option is to evolve a seed industry with both the formal and informal seed systems providing quality seed to the consumers. This will increase the awareness of seed consumers of seed quality and price, and lead to an overall increase in seed use and consequently to agricultural production. Based on the study, the following options were identified:

1. Research institutions providing foundation seed and other inputs to selected farmers through extension services. After harvest, farmers sell certified seed and reimburse the inputs costs to extension services.

2. Potential contract growers are identify by national extension services. The farmers are provided with foundation seed to produce certified seed. In this case, technical advice is given to seed producers by researchers and extension agents.

3. Foundation seeds are given to farmers by researchers. Farmers purchase and apply fertilizer and other inputs. Scientists provide technical assistance to farmers.

4. Non-governmental organizations (NGO's) organize and supply farmers with foundation seed and other inputs for production of certified seed. After seed sales, half of the initial funds are deducted and provided to extension services to encourage seed production by other farmers.

5. Foundation seeds are provided by private seed companies to identified out-growers to produce maize seed. Private seed companies provide incentives such as fertilizer and other inputs to facilitate the production process. After harvest, maize seeds are processed by seed companies and sold as certified seed. The options guarantee maize seed produced by the informal sector.

According to the study, a seed system that would integrate large scale and small scale seed companies with the individual seed productions as presented in option five will provide the best option. The integration can be achieved if the seed producers serve as out-growers or contract growers for the seed companies. The seed companies may also provide technical and financial incentives to the out growers to accelerate and sustain the seed system. In addition, accelerated seed certification and seed quality control will be ensured and there will be sure market for the seed produced by the informal sector. Presently in Nigeria, this option is being adopted by some seed companies in order to meet the needs of their numerous clients, though the integration is not as complimentary and interactive as it should be. This option may seem practicable, a number of analysis have shown that there is a wide diversity in how the two sectors interact (Lanteri and Quagliotti, 1997; Maredia and Howard, 1998).

Strategies to promote informal and formal seed sector integration in Nigeria and Cameroon are:

1. Use of private seed companies as seed producing agencies for large-scale government special seed requirements. This will promote informal seed producers since they will serve as contract growers to the seed companies.

2. Government should organize special programmes to promote awareness of the benefits and use of improved seeds.

3. Government agencies can assist the informal sector by providing foundation seed, extension advice on seed production, processing, treatment and storage and legal framework that permits seed marketing. This will facilitate the growth of small-scale entrepreneurs in the informal sector. This is very relevant in Cameroon where there are no small-scale formal seed producers.

4. Government agencies could provide public goods that are essential to the functioning of both formal and informal sectors including research targeted to maize seed production that are not of interest to the private sector.

\subsection{Conclusion and Recommendations}

The study gave insight into the activities of the small-scale seed producers and the profitability and constraints. Evidence from the study has shown that maize seed industry in WCA (Nigeria and Cameroon in particular) has not developed remarkably. However, maize seed production is profitable. There still exist problems associated with non-availability of foundation seeds, unavailability of land for potential maize seed growers (especially in Cameroon) and unavailability of required manpower in the production process. The important criteria for chosen maize seed variety for planting are market value, grain quality, maturity period and resistance to pests and diseases. According to the study, a seed system that would integrate large scale and small scale seed companies with the individual seed production by way of integrating seed producers as out growers or contract growers to the seed companies seems to be the best option. Finally, government agencies can assist the informal sector by providing foundation seed, extension advice on seed production, processing, treatment and storage and legal framework that 
permits seed marketing. This will facilitate the growth of small-scale entrepreneurs in the informal sector. This is very relevant in Cameroon where there are no small-scale formal seed producers. The evidence provided in this study could lead to the sustainability of maize seed production in WCA where seed companies exist but struggling to survive and could facilitate the establishment of private seed enterprises in Cameroon where none exist. Based on the findings, the following policy recommendations are proposed:

1. Government agencies can encourage the growth of informal maize seed producers by providing them with access to NARS (spell out for initial mention) bred foundation (and/or breeder seed) and given extension advice on seed production, processing, treatment and storage.

2. Appropriate mechanisms should be put in place to strengthen public and private extension programs to increase farmer knowledge about the benefits of using new seed and transmitting information about farmer preferences to researchers will also help increase the demand for new seed.

3. Concerted effort should be made to remove compulsory seed certification and restrictive trade licensing requirements. This permits the production of quality seed by smallholders and sale among neighboring farmers. In addition, seed companies would be able to involve smallholders in contract seed production more easily.

4. Public research and extension agencies also need to consider how to use subsidies to strengthen ties to subsistence farmers who may be unable to purchase seed through the market but could benefit significantly from access to improved varieties.

\section{Recommendations for further study}

Interplay between the legal framework and the seed system in the study area since a very restrictive legal framework involving mandatory varietal notification and seed certification cannot help the growth of the informal sector.

\section{Acknowledgment}

This research work was supported by a grant from the Investment Climate and Business Environment Research Fund, jointly funded by TrustAfrica and IDRC.

\section{References}

[1] Abalu, G.I. (2001). "Policy Issues in Maize Research and Development in sub-Saharan Africa in the Next Millennium". In Badu-Apraku, B., Fakorede, M.A.B., M. Ouedraogo, and R.J. Carsky, (eds.), 2001. Impact, Challenges and Prospects of Maize in West and Central Africa: Proceedings of a Regional Maize Workshop, IITA-Cotonou, Benin Republic, 47 May, 1999. WECAMAN/IITA.
[2] Alimi, T. (2001). "Economic Rationale of Integration in Poultry Production System". Lesotho Social Science Review, $7(2): 138-156$.

[3] Alimi, T., Idowu, E.O. and Tijani, A.A. (2004). "Optimal Farm Size for Profitable and Sustainable Certified Maize Seed Production Enterprise in Oyo State, Nigeria". Botswana Journal of Economics, 1(2):135-146.

[4] Almekinders, C .J. M., Louwaars, N. P. and de Bruijn, G. H. (1994). "Local Seed Systems and their Importance for an Improved Seed Supply in Developing Countries". Euphytica, 78: 207-216.

[5] Byerlee, D and C. Eicher, “1997). “Africa’s Emerging Maize Revolution". Boulder, Colorado, Lynee Rienner Publishers.

[6] Cromwell, E., E. Friss-Hansen, and M. Turner (1992). "The Seed Sector in Developing Countries: A Framework for Performance Analysis". Working Paper 65, Overseas Development Institute, London.

[7] Fakorede, M.A.B, B. Badu-Apraku, A.Y. Kamara, A Menkir and S.O. Ajala. (2003). "Maize Revolution in West and Central Africa: An Overview". In. Badu-Apraku, B., Fakorede, M.A.B., M. ouedraogo, R.J. Carsky, and A. Menkir (eds.), (2003). Maize Revolution in West and Central Africa: Proceedings of a Regional Maize Workshop, IITA-Cotonou, Benin Republic, 14-18 May, 2001. WECAMAN/IITA.

[8] Fakorede, M.A.B, B. Badu-Apraku, O. Coulibaly and J. M Fajemisin (2001). "Maize Research and Development Priories in sub-Saharan Africa in the Next Millennium". In BaduApraku, B., Fakorede, M.A.B., M. Ouedraogo, and R.J. Carsky, (eds.), 2001. Impact, Challenges and Prospects of Maize in West and Central Africa: Proceedings of a Regional Maize Workshop, IITA-Cotonou, Benin Republic, 4-7 May, 1999. WECAMAN/IITA.

[9] Fakorede, M.A.B. (1995). "IITA - Private Seed Companies/NGOs Liaison Activities". A Report of the Current Status and Future Opportunity for a Greater Efficiency in Collaborative Efforts to Improve Maize Production. Pp71.

[10] Gemeda, A., G. Aboma, H. Verkuijl, and W. Mwangi. (2001). "Farmers' Maize Seed Systems in Western Oromia, Ethiopia". Mexico, D.F.: International Maize and Wheat Improvement Center (CIMMYT) and Ethiopian Agricultural Research Organization (EARO). Pp 42.

[11] Ghijsen, H. (1996). "The Development of Varietal Testing and Breeder's Rights in the Netherlands". Pages 223-226. In: Integrating Seed Systems for Annual Food Crops (van Amstel, H., Bottema, J., Sidik, M and van Santen, C., eds.) Bogor, Indonesia: CGPRT Centre.

[12] Jaffee, S. and J. Srivastava (1994). "The Roles of the Private and Public Sectors in Enhancing the Performance of Seed Systems". The World Bank Development. The World Bank for the Construction and Development. The World Bank, 9(1).97-117.

[13] Jose, H.D. and Valluru, R.S.K. (1997). "Insight from the Crop Insurance Reform Act of 1994". Agribusiness, 13(6). 587-598.

[14] Langyinto, A. (2005). "An Analysis of the Maize Seed Sector in Southern Africa". A paper presented at a Rockefeller Foundation Workshop on Biotechnology, Breeding and Seed Systems for African Crops. Nairobi, Kenya 24-27 January, 2005. Pp25. 
[15] Lanteri, S. and Quagliotti, L. (1997). "Problems Related to Seed Production in the African Region". Euphytica, 96:173183.

[16] Louwaars, M.P. and G.A.M. Marrewijk (1999). Seed Supply Systems in Developing Countries, CTA.

[17] Manyong, V.M., J.G. Kling, K.O. Makinde, S.O. Ajala, and A. Menkir. (2000). "Impact of IITA-improved Germplasm on Maize Production in West and Central Africa". Impact, IITA, Ibadan, Nigeria.

[18] Maredia, M., and J. Howard, (1994). "Facilitating Seed Sector Transformation in Africa: key fingings from the literature". Global Bureau, Office of Agriculture and Food Security. USAID. Policy Systhesis, 33.1-6.

[19] Maredia, M., J. Howard, and D. Boughton, with A. Naseem, M. Wanzala, and K. Kajisa (1999). "Increasing Seed System Efficiency in Africa: Concepts, Strategies and Issues". MSU (Michigan State University) International Development Working Paper No. 77.

[20] Morris M. L., J. Rusike and M. Smale. (1998). "Maize Seed Industries: A Conceptual Framework". In Morris M. L. (ed.) Maize Seed Industries in Developing Countries. Boulder, Colorado: Lynne Rienner Publishers. pp. 35- 54.

[21] Monyo, E. S. (1998). “Analytical Review of Regional Impacts of SMIP: 15 Years of Pearl Millet Improvement in the SADC Region". Paper presented at Sorghum and Pearl Millet and Development in Southern Africa: Stakeholders Review and Planning Conference. 27-31 Jul. 1998. Harare. Zimbabwe. SADC/ICRISAT Sorghum and Millet Improvement Programme. Bulawayo Zimbabwe.

[22] Musa, T. M., and van der Mheen-Sluijer, J. (1977). "Review of the State of Art in the Field of Local Level Seed Supply Systems". Harare. Published by SADC/GTZ Project Promotion of Small Scale Seed Production by Self Help Groups.

[23] Musa, T. M, and Rusike, J. (1997). "Constraints on Variety Release, Seed Production and Distribution of Sorghum, Pearl Millet, Groundnut and Pigeonpea". ICRISAT Southern and Eastern Africa Region Working Paper No 97/02 (SADC/ICRISAT-SMIP). Matopos.

[24] Nambiro, E, H. De Groote and W. O. K'osura (2002). "Market Structure and Conduct of the Hybrid Maize Seed Industry, a Case Study of the Trans Nzoia District in Western
Kenya”. In Friesen D.K. and A. F. E. Palmer (eds.). Integrated Approaches to Higher Maize Productivity in the New Millenium. Proceedings of the 7th Eastern and Southern Africa Regional Maize Conference, Nairobi, Kenya, 11 - 15 February 2002. Mexico, D. F.: CIMMYT, pp. 474-479.

[25] Odendo M., H. De Groote, O. Odongo and P. Oucho. (2002). "Participatory Rural Appraisal of Farmers' Maize Selection Criteria and Perceived Production Constraints in the Moist Mid-altitude Zone of Kenya". IRMA Socio-Economic Working Paper No. 02-01. Nairobi, Kenya: CIMMYT and KARI.

[26] Omaliko, C.P.E. (1998). "Nigeria Seed Industry and its Potential Role in Food Security within the West and Central African Sub-region". Proceedings of the International workshop on Seed security for food security. Florence, Italy, 30 November - 1 December 1997. FAO 1998.

[27] Rohrbach, D. D. (1997). "Farmer to Farmer Seed Movements in Zimbabwe: Issues Arising". Pages 171- 179. In: Alternative Strategies for Smallholder Seed Supply. Proceedings of the International Conference on Options for Strengthening National and Regional Systems in Africa and West Asia..1014 Mar. 1997, Harare, Zimbabwe. Rohrbach, D. D.. Bishaw, Z, and van Gastel A. J. G.; (eds.). International Crops Research Institute for the Semi-Arid Tropics.

[28] Smith, J., A.D. Barau, A. Goldman, and J.H. Mareck. (1994). "The Role of Technology in Agricultural Intensification: the Evolution of Maize Production in the Northern Guinea Savanna of Nigeria". Economic Development and Cultural Change, 42. 537-554.

[29] Smith, J., G. Weber, V.M. Manyong, and M.A.B. Fakorede (1997). "Fostering Sustainable Increases in Maize Productivity in Nigeria". Chapter 8 in Africa's Emerging Maize Revolution, edited by D. Byerlee, and C.K. Eicher, Lynne Rienner Publishers, London, UK.

[30] Tripp, R. B. (1977). "Between States and MarketsInnovations for Small Scale Seed Provision". Pages 195- 210 In: Alternative Strategies for Smallholder Seed Supply. Proceedings of the International Conference on Options for Strengthening National and Regional Systems in Africa and West Asia..10-14 Mar. 1997, Harare, Zimbabwe (Rohrbach, D. D.. Bishaw, Z, and van Gastel A. J. G.; eds.). International Crops Research Institute for the Semi-Arid Tropics.

[31] Venkatesan., V. (1994). Seed Systems in Sub-Saharan Africa: Issues and Options. Discussion Paper No. 266. Technical Department, Africa Region. Washington, D.C.: World Bank. 